\title{
Media Pembelajaran Berbantuan Sparkol Materi Program Linier Metode Simpleks
}

\author{
Indriyani ${ }^{1 *}$, Fredi Ganda Putra ${ }^{1}$ \\ 1Universitas Islam Negeri Raden Intan Lampung. Jalan Endro Suratmin, Sukarame, Bandar \\ Lampung 35133, Indonesia. \\ *Corresponding Author. E-mail: indriyani7423@gmail.com
}

Received : 13-08-2018; Revised : 19-09-2018; Accepted : 30-09-2018

\begin{abstract}
Abstrak
Matematika merupakan sarana komunikasi sains tentang pola-pola yang berguna untuk melatih berfikir logis, kritis, kreatif dan inovatif. Pentingnya matematika dalam pendidikan berbanding terbalik dengan minat siswa, karena matematika dianggap sulit dan membosankan, untuk itu perlu adanya inovasi dalam pembelajaran agar matematika tampak mudah dan menarik yaitu salah satunya denganmengembangkan media pembelajaran dalam bentuk video dengan menggunakan aplikasi Sparkol Videoscribe. Tujuan dari penelitian ini adalah engembangkan media pembelajaran matematika menggunakan software Sparkol Vidieoscribe pada pkok bahasan program linier metode simpleks, serta menguji kelayakan nya dan mengetahui respon mahasiswa terhadap media tersebut. Penelitian ini menggunakan model ADDIE yang meliputi 5 langkah yaitu : analisis (analyze), perencanaan (design), pengembangan (development), implementasi (implementation), dan evaluasi (evaluation). Kelayakan media pembelajaran diperoleh dari hasil validasi oleh ahli media dan ahli materi dengan kategori layak, dan kemenarikan video diperoleh dari data angket yang diisi oleh mahasiswa meliputi kelas kecil dan kelas besar dan secara kualitatif berkualifikasi menarik.
\end{abstract}

Kata kunci : media pembelajaran, sparkol videoscribe, metode simpleks

\begin{abstract}
Mathematics is a means of communication science about patterns that are useful to practice thinking logically, critically, creative and innovative. The importance of mathematics in education is inversely related to the interest of students, because mathematics is considered to be difficult and tedious, it is necessary for the innovation in learning so that math seems easy and interesting, namely one of them with developing a learning media in the form of a video by using the app Sparkol's video scribe. The purpose of this research is learning media math using software Sparkol Video scribe on the main discussion of linear program simplex method, as well as test the feasibility and know the response of students to the media. This study uses a model ADDIE which includes 5 steps, namely: analysis (analyze), planning (design), development (development), implementation (implementation), and evaluation (evaluation). The feasibility of learning media obtained from the results of the validation by media experts and matter experts with the category and the attractiveness of the video data obtained from a questionnaire filled by the students include small class and large class and qualitatively qualified interesting.
\end{abstract}

Key words : learning media, sparkol videoscribe, simpleks methode 


\section{PENDAHULUAN}

Ilmu pengetahuan dan teknologi berkembang sangat pesat, sehingga proses pembelajaran yang memanfaatkan media pembelajaran berbasis teknologi informasi (TI) menjadikan pendidik sebagai fasilitator (Rusman, 2013). Siswa ataupun mahasiswa dapat belajar di mana dan kapan saja sesuai dengan minat belajarnya masing-masing tanpa tergantung kepada kehadiran pendidik di kelas (Suparno, 2001). Seorang pendidik dituntut untuk dapat merancang pembelajaran untuk memanfaatkan berbagai jenis media belajar berbasis TI yang sesuai agar proses pembelajaran berlansung efektif dan efisien (Sanjaya, 2013). Jenis media pembelajaran berbasis TI beraneka ragam, diantaranya foto, slide, film, video, dan komputer (Wulandari, 2016). Penerapan media yang berbasis TI dapat diterapkan pada beberapa mata kuliah untuk mahasiswa yakni program liner metode simpleks.

Berdasarkan hasil wawancara terhadap rekan-rekan mahasiswa UIN Raden Intan Lampung tentang mata kuliah Program Linier pada pokok bahasan metode simpleks, diperoleh informasi bahwa kesulitan belajar pada mata kuliah ini dikarenakan membutuhkan ketelitian yang lebih di banding mata kuliah yang lain, hal ini dikarenakan program linier metode simpleks ini merupakan penyelesaian masalah pemrograman linier dengan banyak variabel, melalui melalui serangkaian operasi-operasi berulang, yang membutuhkan pemahaman perkalian, penjumlahan dan pengurangan serta manajemen waktu dalam mengerjakan soal.

Berdasarkan hasil wawancara dengan dosen yang mengampu mata kuliah program linier, terdapat kurang dari $50 \%$ nilai mahasiswa tidak lulus dan lulus dengan nilai di bawah standar kategori baik, yaitu di mulai dari angka 65-100. Rendahnya nilai hasil belajar mahasiswa tersebut juga disebabkan kurangnya bahan ajar yang menarik dan tidak monoton. Berdasarkan wawancara dengan dosen yang mengampu mata kuliah program linier, diperoleh informasi bahwa dalam proses pembelajaran dosen masih menggunakan buku sebagai bahan ajar utama dan belum menggunakan media pembelajaran sebagai alat bantu, oleh karena itu diperlukan suatu media agar menarik perhatian serta memotivasi mahasiswa untuk sering berlatih dalam mengerjakan soal sehingga dapat terlatih pula ketelitian dan manajemen waktu dalam mengerjakan soal.

Pendidik dapat menanfaatkan jenis media pembelajaran berbasis TI untuk menghadapi masalah tersebut. Media yang menjadikan satu kesatuan antara gambar, slide, video, dan ditambah adanya suara. Salah satu yakni media berbasis Sparkol video scribe yang mampu membuat video berupa animasi, gambar, tulisan dan suara.

Beberapa penelitian terdahulu juga telah mengembangkan media pembelajaran beruba sparkol video scribe pada beberapa mata pelajaran seperti fisika, sosiologi, TBK, dan IPA (Putra Purnama, erlidawati, Muhammad Nazar, 2016; Ilham Musyadat, 2015; Nur Wahyuni, Edy Sulistiyo, 2017; Dyah Ayu Wulandari, 2016). Penelitian juga dilakukan oleh Daryanto yang menyatakan pentingnya media pembeajaran dalam proses pembelajaran (Daryanto, 2010). Penelitian-penelitian dilakukan untuk meningkatkan hasil dan minat belajar siswa.

Berdasarkan beberapa penelitian terdahulu dan permasalahan yang dihadapi mahasiswa seperti yang telah 
Desimal, 1 (3), 2018 - 355

Indriyani, Fredi Ganda Putra

disebutkan, maka peneliti bermaksud untuk mengembangkan media pembelajaran berbantuan sparkol pada materi program linear metode simpleks. METODE

Jenis penelitian yang digunakan dalam penelitian ini adalah Research and Development (R\&D). Penelitian dan pengembangan merupakan suatu proses atau langkah-langkah untuk mengembangkan suatu produk atau menyempurnakan produk yang telah ada dan dapat dipertanggungjawabkan. Metode penelitian dan pengembangan digunakan untuk menghasilkan produk tertentu, dan menguji keefektifan produk tersebut (Sugiyono, 2016b).

Prosedur penelitian yang digunakan pada penelitian ini menggunakan model penelitian yang dikembangkan oleh ADDIE, yang memiliki lima langkah penelitian dan pengembangan, yaitu :(1) Analysis(Analisis), yaitu tahap identifikasi masalah yang dilakukan
Perbedaan dengan penelitian terdahulu terletak pada maetri yang akan diangkat dalam penelitian.

untuk mendapatkan informasi dan menganalisis permasalahan. (2) Design (Perancangan), yaitu memuat rancangan dalam pembuatan produk yang telah ditetapkan. (3) Development (Pengembangan), yaitu kegiatan pengembangan rancangan menjadi sebuah produk dan menguji kevalidannya. Uji validasi dilakukan oleh validator (ahli media, ahli materi). (4) Implemantation (Implementasi), yaitu tahap dimana produk yang telah di validasi akan di uji cobakan kepada mahasiswa pendidikan matematika UIN Raden Intan Lampung. (5) Evaluation(Evaluasi), yaitu tahap untuk menilai kualitas dari produk yang sudah dikembangkan. Berikut ini bagan prosedur pengembangan ADDIE (Sugiyono, 2016a)

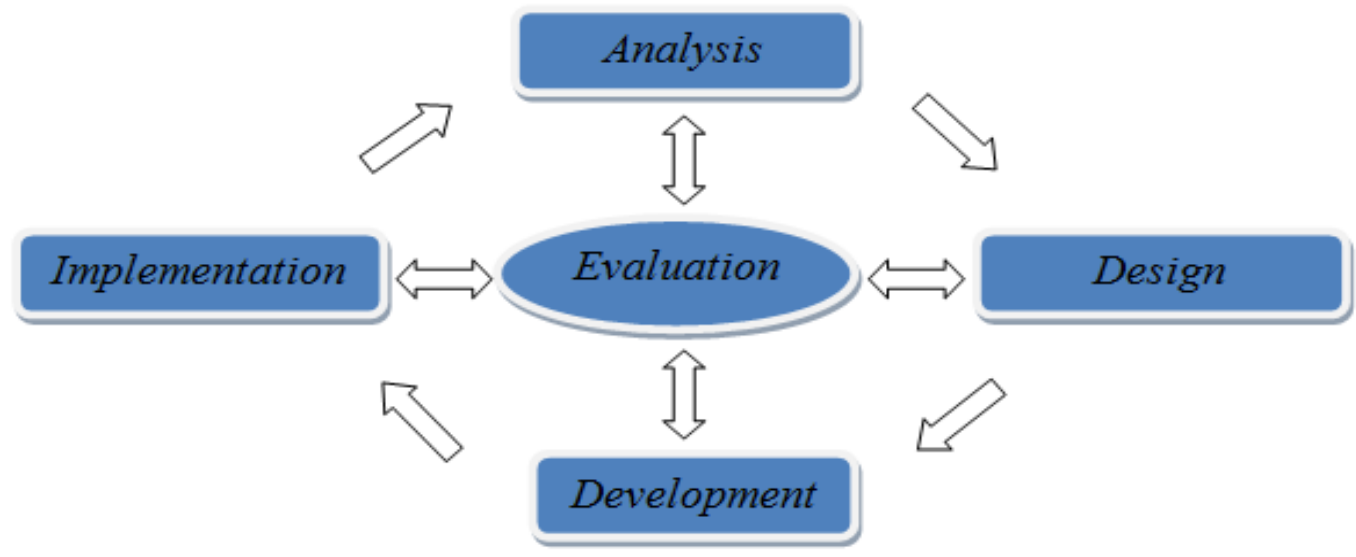

Gambar 1. Gambar bagan prosedur penelitian ADDIE

Teknik analisis data pada penelitian ini menggunakan teknik analisis deskriptif kualitatif yang memaparkan hasil pengembangan produk yang berupa video pembelajaran berbantuan sparkol videoscribe. Data yang diperoleh melalui instrumen uji coba dianalisis dengan menggunakan statistik deskriptif kualitatif. Instrumen yang digunakan memiliki 4 jawaban, yaitu Sangat Baik (SB) diberi skor 4, Baik (B) skor 3, Cukup (C) skor 2, dan Kurang baik (KB) skor 1. Sehingga skor penilaian total dapat dicari dengan menggunakan rumus sebagai berikut (Dewi, 2016). 
Desimal, 1 (3), 2018 - 356

Indriyani, Fredi Ganda Putra

$$
\bar{x}=\frac{\sum_{i=1}^{n} x_{i}}{n}
$$

Dengan

Keterangan:

$$
x_{i}=\frac{\text { Jumlah Skor }}{\text { Skor maks }} \times 4
$$

$\bar{x}=$ rata - rata akhir

$x_{i}=$ nilai uji operasional

$n=$ banyaknya responden

Kevalidan media diperoleh dari respon ahli media dan ahli materi dengan kualifikasi penilaian pada Tabel 1.

\section{Tabel 1. Kualifikasi Penilaian}

\begin{tabular}{cc}
\hline Kategori & Skor \\
Sangat Baik & 4 \\
Baik & 3 \\
Kurang & 2 \\
\hline
\end{tabular}

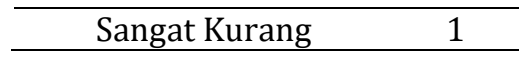

Tabel 1 menunjukkan macammacam skor yang harus diberikan oleh para ahli untuk memberikan penilaian pada media yang dikembangkan. Pada tabel juga disertai dengan kriteria dari skor yang diperoleh.

Hasil dari skor penilaian dari masing-masing validator ahlitersebut kemudian dicari rata-ratanya dan dikonversikan ke pertanyaan untuk menentukan kevalidan dan kelayakan video pembelajaran berbantuan Sparkol video scribe. Penkonversian skor menjadi pertanyaan penilaian ini dapat dilihat dalam $\quad$ Tabel 2.

Tabel 2. Kriteria Validasi Ahli

\begin{tabular}{rll}
\hline Skor Kualitas & Kriteria Kelayakan & \multicolumn{1}{c}{ Keterangan } \\
\hline $3.26<\bar{x} \leq \mathbf{4 , 0 0}$ & Valid & Tidak Revisi \\
$\mathbf{2 , 5 1}<\bar{x} \leq \mathbf{3 , 2 6}$ & Cukup Valid & Revisi Sebagian \\
$\mathbf{1 , 7 6}<\bar{x} \leq \mathbf{2 , 5 1}$ & Kurang Valid & $\begin{array}{l}\text { Revisi Sebagian \& Pengkajian Ulang } \\
\text { Materi }\end{array}$ \\
$\mathbf{1 , 0 0}<\bar{x} \leq \mathbf{1 , 7 6}$ & Tidak Valid & Revisi Total \\
\hline
\end{tabular}

Tabel 2 menunjukkan interval nilai total yang diberikan oleh para ahli dan peneliti dapat mengetahui tingkat kevalidan serta perlu atau tidaknya dilakukan revisi.
Kemenarikan media pembelajaran diperoleh dari respon mahasiswa terhadap media tersebut melalui angket dengan kualifikasi penilaian yang dirangkum dalam Tabel 3.

Tabel 3. Skor penilaian Terhadap Pilihan Jawaban

\begin{tabular}{lc}
\hline \multicolumn{1}{c}{ Kategori } & Skor \\
Sangat Setuju & 4 \\
Setuju & 3 \\
Cukup Setuju & 2 \\
Kurang Setuju & 1 \\
\hline
\end{tabular}

Tabel 3 menunjukkan skor penilaian untuk mahasiswa disertai dengan jenis kategorinya. Mahasiswa dapat memberikan skor sesuai dengan tingkat kemenarikan dari media yang dikembangkan.
Hasil dari skor penilaian dari masing-masing mahasiswatersebut kemudian dicari rata-rata dan dikonversikan ke pertanyaan untuk melihat kriteria responmahasiswa. Penkonversian skor menjadi pertanyaan penilaian ini dapat dilihat dalam Tabel 4 
Desimal, 1 (3), 2018 - 357

Indriyani, Fredi Ganda Putra

Tabel 4. Kriteria Uji kemenarikan

\begin{aligned} & \hline Skor Kualitsa \multicolumn{1}{c}{ Kriteria } \\ & $3.26<\bar{x} \leq 4,00$ Sangat Menarik \\ & $2,51<\bar{x} \leq 3,26$ Menarik \\ & $\mathbf{1 , 7 6}<\bar{x} \leq 2,51$ Kurang Menarik \\ & $\mathbf{1 , 0 0}<\bar{x} \leq \mathbf{1 , 7 6}$ Sangat Kurang Menarik \\ & \hline\end{aligned}

Tabel 4 merupakan interval nilai ratarata akhir dari penilaian kemenarikan media yang diberikan oleh mahasiswa. Dengan interval tersebut, peneliti dapat mengetahui tingkat kemenarikan media.

\section{HASIL DAN PEMBAHASAN}

Penelitian dan pengembangan ini menggunakan model pengembangan ADDIE dengan tahapan sebagai berikut

\section{Tahap Analisis}

Dari hasil analisis karakteristik mahasiswa yang diperoleh dari wawancara dengan dosen dan mahasiswa, secara umum siswa dapat mengikuti perkuliahan namun masih terdapat kesulitan saat mengerjakan tugas diluar jam kuliah dan kesulitan saat ujian. Sedangkan hasil analisis kebutuhan dalam beberapa aspek yaitu : (1) nalisis kurikulum, materi program linier metode simpleks terdapat pada kurikulum program study pendidikan matematika di semster 4. (2) analisis media pembelajara. Media yang digunakan pada proses pembelajaran hanya menggunakan buku cetak yang kurang menarik, sehingga mahasiswa kurang tertarik untuk membaca buku diluar jam perkuliahan. Maka dari itu peneliti mengembangkan media pembelajaran dalam bentuk video, diharapkan agar dapat membantu mahasiswa untuk belajar dan memahami materi tersebut.

\section{Tahap perancangan}

Dari hasil analisis yang didapat kemudian peneliti melakukan perancangan, spesifikasi media yang dibuat yaitu berupa video yang dibuat menggunakan aplikasi sparkol videoscibe. Berikut perancangan video yang dikembangkan : (a) Membuat cover sebagai perkenalan video

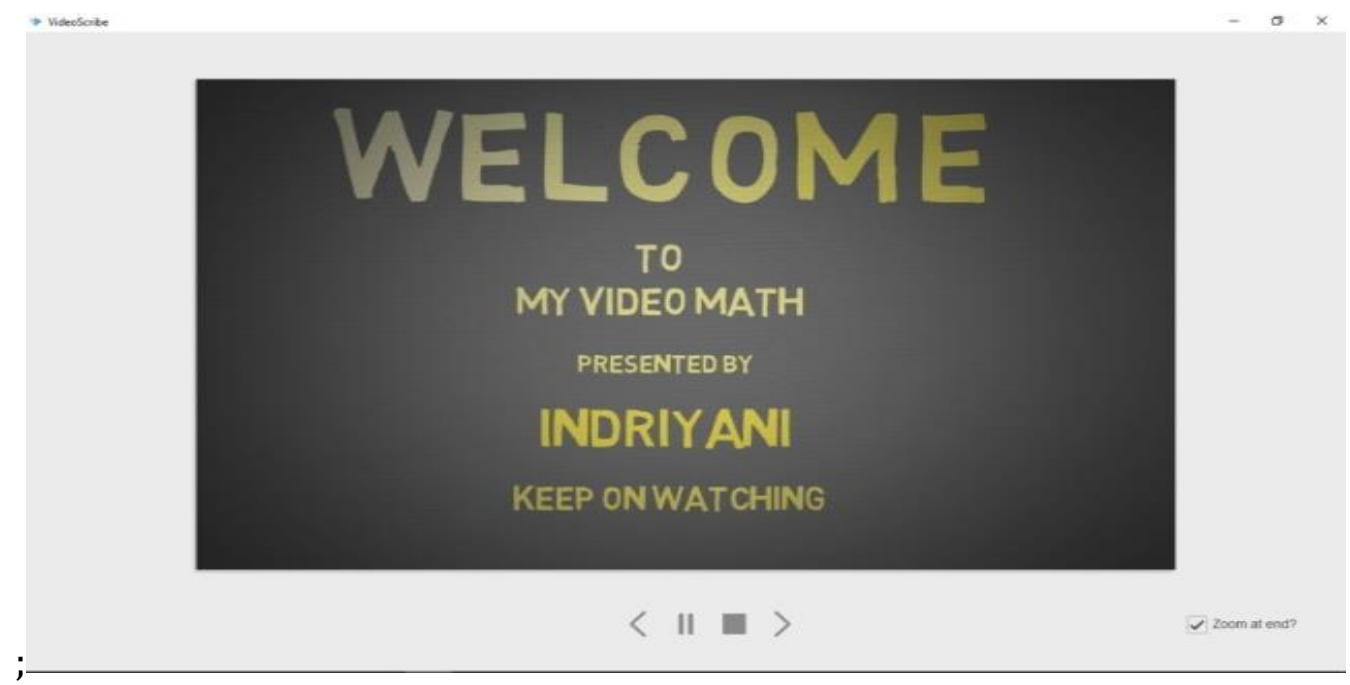

Gambar 2. Desain cover media pembelajaran 
Desimal, 1 (3), 2018 - 358

Indriyani, Fredi Ganda Putra

Gambar 2 menunjukkan rancangan awal cover media pembelajaran yang dikembangkan. Pada slide cover dicantumkan ucapan selamat datang dan nama pengembang media.

(b) Membuat konsep pengetahuan secara umum tentang metode simpleks

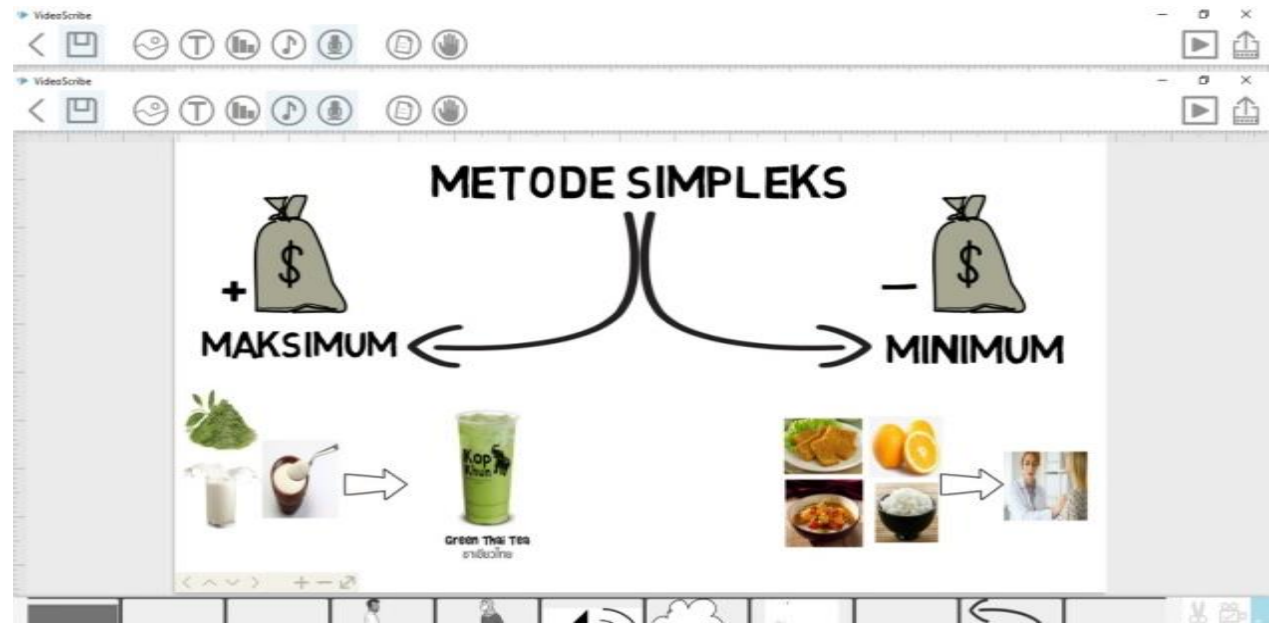

Gambar 3. Tampilan desain konsep umum metode simpleks

Gambar 2 merupakan tampilan desain konsep umum metode simpleks yang disertai dengan gambar penerapan dalam kehidupan seharihari.

(c) Mengenalkan tablo simpleks secara umum serta langkah-lanhkah penyelesaian nya

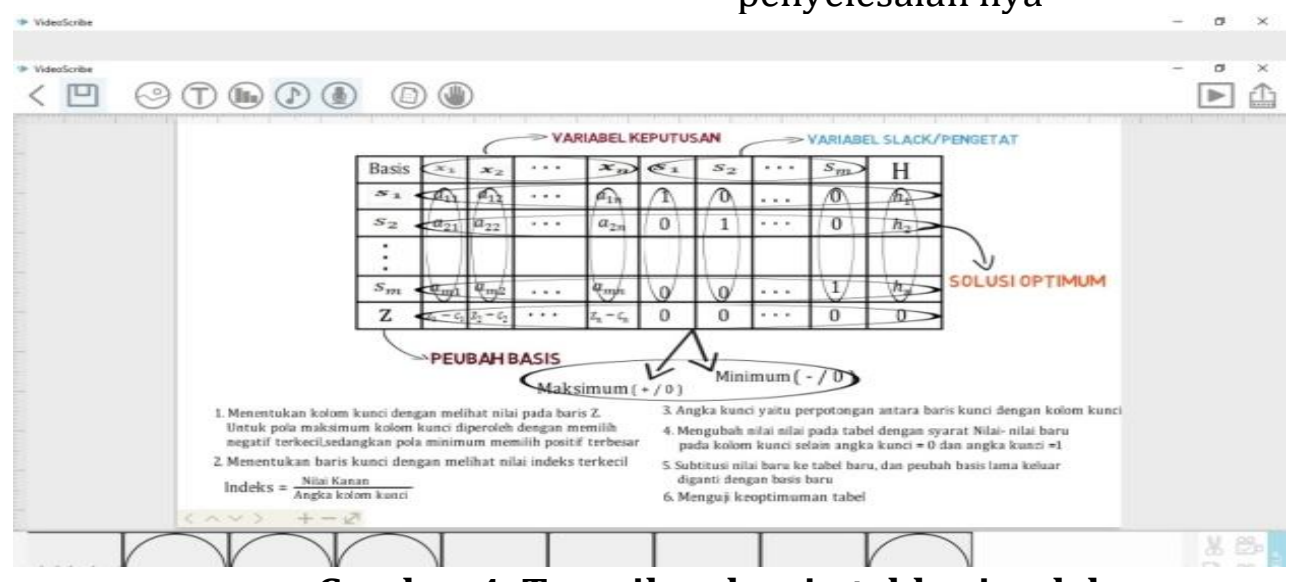

Gambar 4. Tampilan desain tablo simpleks

Gambar 4 memperlihatkan desain pada tabel simpleks. Tabel yang disediakan disertai dengan keterangan cara pengerjaan dan keteranganketerangan yang perlu diketahui dalam pembuatan tabel. 
Desimal, 1 (3), 2018 - 359

Indriyani, Fredi Ganda Putra

(d) Membuat contoh soal dan penyelesaian

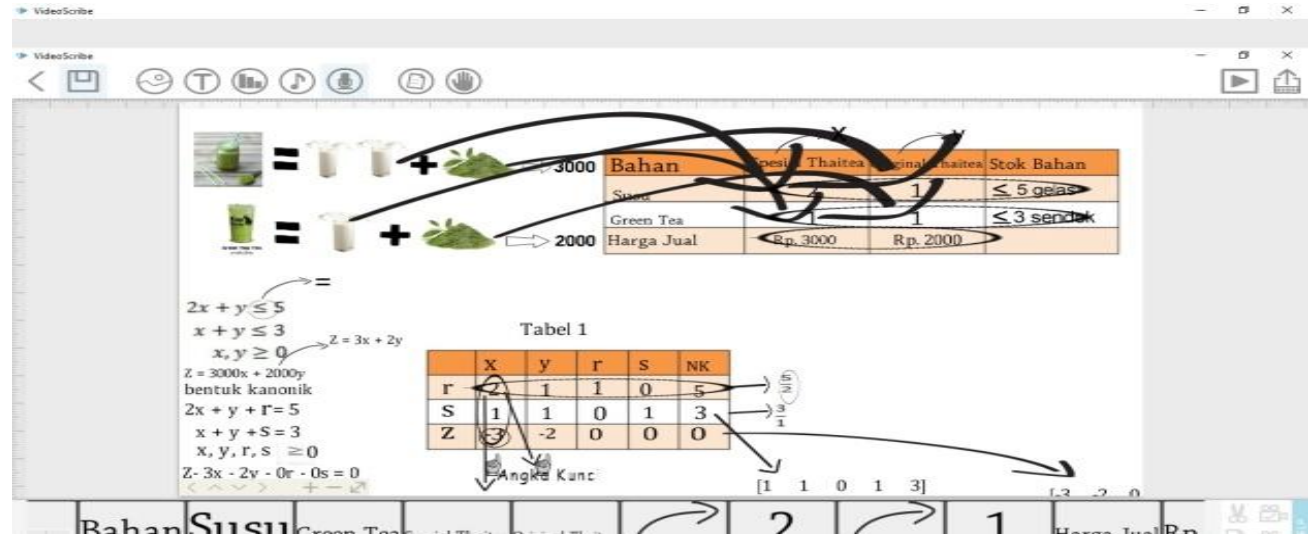

Gambar 5. Tampilan contoh soal

Gambar 5 merupakan tampilan pada contoh soal yang disertai dengan langkah mengerjakan secara detail.

(e) Kesimpulan penyelesaian soal

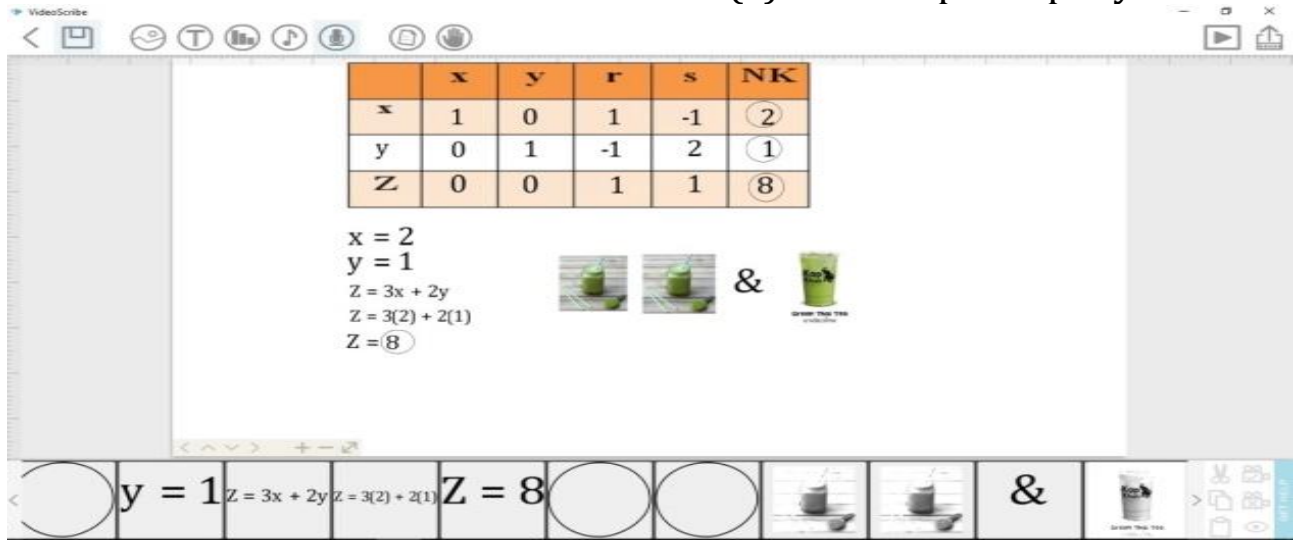

Gambar 6. Tampilan kesimpulan

Gambar 6 menunjukkan desain dari kesimpulan. Kesimpulan dapat berupa tabel akhir dan diketahui masingmasing nilai yang dicari kemudian dikaitkan kembali dengan soal awal yang memanfaatkan kehidupan seharihari.

(f) Rekaman suara untuk menjelaskan materi pada video tersebut (g) Menyimpan video dalam bentuk file (h) Menggabungkan video menggunakan aplikasi movie maker.

\section{Tahap pengembangan}

Setelah perancangan produk telah selesai maka langkah selanjutnya yaitu pengembangan. Pada tahap pengembangan pertama yaitu dengan menguji kelayakan media dengan memvalidasi produk oleh tim validator yang terdiri dari 6 ahli yaitu 3 ahli materi dan 3 ahli media. Adapun hasil dari validasi oleh ahli yang diperoleh dari pengisian angket diperoleh hasil yang disajikan dalam Tabel 5 . 
Desimal, 1 (3), 2018 - 360

Indriyani, Fredi Ganda Putra

Tabel 5. Rata-rata penilaian validasi ahli materi tiap aspek

\begin{tabular}{llll}
\hline No. & Aspek & Validasi tahap 1 & Validasi tahap 2 \\
1 & Kesesuaian materi dengan SK dan KD & 2,167 & 3,167 \\
2 & Keakuratan Materi & 3 & 3,78 \\
3 & Mendorong keingintahuan & 3 & 3,67 \\
4 & Teknik penyajian & 3 & 3,67 \\
5 & Penyajian pembelajaran & 3 & 3 \\
6 & Koherensi dan keruntutan alur & 3 & 3,33 \\
7 & Kontekstual & 3 & 3,5 \\
& $\quad$ Rata-rata & 2,881 & 3,45 \\
\hline
\end{tabular}

Berdasarkan Tabel 5 memperlihatkan hasil validasi ahli materi di atas, terlihat bahwa pada validasi tahap 1 memperoleh rata-rata kembali ditahap 2 diperoleh rata-rata 3,45 dengan kualifikasi valid. Dengan demikian hasil validasi ahli materi tahap skor 2,881 dengan kualifikasi cukup valid yang artinya masih harus diperbaiki. Setelah melakukan perbaikan dan divalidasi 2 media dinyatakan valid/layak digunakan sebagaimana mestinya.

Tabel 6. Rata-rata penilaian validasi ahli media tiap aspek

\begin{tabular}{clll}
\hline No. & \multicolumn{1}{c}{ Aspek } & Validasi tahap 1 & \multicolumn{1}{c}{ Validasi tahap 2 } \\
1 & Pewarnaan & 2,67 & 3,167 \\
2 & Pemakaian kata dan bahasa & 3 & 3,417 \\
3 & Tampilan pada layar & 2,89 & 3,28 \\
4 & Penyajian & 2,78 & 3,22 \\
5 & Animation dan suara & 3 & 3,33 \\
Rata-rata & 2,87 & 3,28 \\
\hline
\end{tabular}

Berdsarkan Tabel 6 menunjukkan hasil uji validasi yang dilakukan ahli media, terlihat pada alidasi tahap 1 memperoleh rata-rata skor sebesar 2,87 dengan kriteria "cukup valid", yang artinya perlu adanya perbaikan agar media layak untuk digunakan. Setelah dilakukan perbaikan dan divalidasikan ualng kepada ahli media diperoleh ratarata skor 3,28 dengan kriteria "valid" yang artinya sudah layak dan tidak perlu adanya perbaikan ulang. Berdasarkan hasil validasi baik ahli maupun ahli media keduanya menyatakan bahwa produk yang dikembangkan layak untuk dipergunakan mahasiswa sebagai alat bantu belajar mandiri dan juga digunakan dalam perkuliahan program linier pada pokok bahasan metode simpleks.

\section{Tahap implementasi}

Setelah produk divalidasi kemudian direvisi sehingga mendapatkan kriteria layak untuk digunakan, maka selanjutnya yaitu mengimplementasikan media untuk utnuk dipergunakan sebagai mana mestinya, namun sebelumnya produk di uji coba kemenarikan oleh mahasiswa yang dikelompokan dalam 2 kelompok yaitu kelas kecil dan kelas besar dengan kelas kecil terdiri dari 11 mahasiswa dan kelas besar terdiri dari 25 mahasiswa prodi pendidikan matematika Universitas Islam Negeri Raden Intan Lampung. Hasil uji coba 
Desimal, 1 (3), 2018 - 361

Indriyani, Fredi Ganda Putra

tersebut disajikan dalam tabel berikut ini:

Tabel 7. Hasil rata-rata uji coba produk

\begin{tabular}{llr}
\hline No & Kelompok kelas & Skor rata-rata \\
$\mathbf{1}$ & Kelas kecil & 3,26 \\
$\mathbf{2}$ & Kelas besar & 3,30 \\
\hline
\end{tabular}

Berdasarkan Tabel 7 memperlihatkan hasil uji coba media yang dikembangkan. Uji coba dilakukan pada skala kecil dan besar. Pada skala kecil memperoleh skor rata-rata 3,26 dan pada skala besar memperoleh skor ratarata 3,30. Dengan demikian, berdasarkan interval kriteria uji coba maka media pembelajaran yang dikembangkan dalam kriteria sangat menarik.

Berdasarkan penilaian dan uji coba media yang telah dilakukan, maka menghasilkan media pembelajaran yang berbasis sparkol sangat layak dan sangat menarik untuk digunakan. Penelitian yang dilakukan memiliki kesamaan dengan penelitian-penelitian terdahulu yakni menghasilkan media pembelajaran berbasis Sparkol video scribe yang valid, layak, dan menarik untuk digunakan (Putra Purnama, erlidawati, Muhammad Nazar, 2016; Ilham Musyadat, 2015; Nur Wahyuni, Edy Sulistiyo, 2017; Dyah Ayu Wulandari,2016).

\section{SIMPULAN DAN SARAN}

Berdasarkan hasil pengembangan media pembelajaran berbantuan sparkol videoscribe pada materi program linier metode simpleks dengan menggunakana model pengembangan ADDIE dapat disimpulkan bahwa produk layak digunakan setelah melakukan proses validasi kemudian direvisi dan menarik menurut respon mahasiswa. Adapun langkah-langkah pengembangannya yaitu (1). Analisis
(Analyze), (2). Perancangan (Design), (3). Pengembangan (Development), dan (4). Evaluasi (Evaluation).

\section{DAFTAR PUSTAKA}

Daryanto. (2010). Media Pembelajaran: Peranannya Sangat Penting Dalam Mencapai Tujuan Pembelajaran. Yogyakarta: Gava Media

Dewi, R. (2016). Pengembangan Lembar Kerja Peserta Didik Berbasis Inkuiri Terbimbing Pada Materi Operasi Hitung Bentuk Aljabar Di Smp. UIN Raden Intan Lampung, Lampung.

Musyadat, I. (2015). Pengembangan Media Pembelajaran Berbasis Video Scribe Untuk Peningkatan Hasil Belajar Pada Mata Pelajaran Sosiologi Kelas X MAN Bangil. skripsi. UIN Maulana Malik Ibrahim

Purnama, P., Erlidawati, Muhammad, N. (2016). Pengembangan Media Video Animasi Berbasis Video Scribe Pada Materi Koloid Untuk Mahasiswa Program Studi Pendidikan Fisika Tahun Ajaran 2016/2017. Jurnal Ilmiah Mahasiswa Pendidikan Kimia (JIMPK), 2 (3), 253-260.

Rusman. (2013). Model-model Pembelajaran: Mengembangkan Profesionalisme Guru. Jakarta: Rajawali Pers

Sanjaya, W. (2013). Perencanaan dan Desain Sistem Pembelajaran. Jakarta: Kencana 
Desimal, 1 (3), 2018 - 362

Indriyani, Fredi Ganda Putra

Suparno. (2001). Psikologi Pendidikan. Bandung; Pustaka Setia

Sugiyono. (2016a). Metode Penelitian \& Pengembangan (Research and Develpment / $R \& D$ ). Bandung: Alfabeta.

Sugiyono. (2016b). Metode Penelitian Pendidikan. Bandung: Alfabeta.

Wahyuni, N. dan Edy, S. (2017). Pengembangan Media Pembelajaran Compact Disc Interactive (CD-i) Berbasis Video Scribe Menggunakan Model Pembelajaran Advance Organizer Pada Mata Pelajaran TBK Kelas X TAV Di SMK Negeri 3 Surabaya.
Jurnal Pendidikan Teknik Elektro, 6, 161-166

Wulandari, D. A. (2016). Pengembangan Media Pembelajaran Menggunakan Sparkol Video Scribe Dalam Meningkatkan Minat Belajar Siswa Pada Mata Pelajaran IPA Materi Cahaya Kelas VIII Di SMP Negeri 01 Kerjo Tahun Ajaran 2015/2016. Skripsi. Universitas Negeri Semarang. 